\title{
Tricuspid regurgitation after implantable cardioverter-defibrillator implantation in patients with arrhythmogenic right ventricular cardiomyopathy
}

\author{
Niedomykalność trójdzielna po implantacji wszczepialnego kardiowertera- \\ -defibrylatora u pacjentów z arytmogenną kardiomiopatią prawej komory
}

\author{
Krzysztof Bernard Poślednik ${ }^{1}$, Olgierd Woźniak ${ }^{1}$, Elżbieta Katarzyna Biernacka ${ }^{1}$, \\ Marek Konka ${ }^{1}$, Andrzej Przybylski ${ }^{2}$, Łukasz Szumowski ${ }^{2}$, Piotr Hoffman ${ }^{1}$ \\ ${ }^{1}$ Department of Congenital Heart Diseases, Institute of Cardiology, Warsaw-Anin, Poland \\ ${ }^{2}$ Department of Arrhythmia, Institute of Cardiology, Warsaw
}

\begin{abstract}
Introduction. The problem of lead-induced tricuspid regurgitation (LITR) in patients with arrhythmogenic right ventricular cardiomyopathy (ARVC) is poorly investigated. Patients with high risk of adverse outcome usually receive implantable cardioverter-defibrillator (ICD) as a prevention of sudden cardiac death (SCD). Unfortunately, the insertion of ICD into the right ventricle is supposed to exacerbate tricuspid regurgitation.

As ICD (or cardiac resynchronization therapy defibrillator) seems to be necessity in prevention of SCD in quite large group of patients, we aimed to evaluate frequency of LITR and further outcome in these persons.

Material and methods. In a database of 55 patients with ARVC and ICD implanted in prevention of SCD, we selected 35 patients (mean age $48.78 \pm 13.56$ years) with data suitable for analysis. Based on the results of echocardiography, study population was divided into 2 groups: TR+ group with worsening of tricuspid regurgitation (TR) defined as its deterioration to higher grade and TR- group (without worsening of TR).

Results. In $65.71 \%$ of patients TR worsened after ICD implantation. Mean time of observation was $91.06 \pm 55.32$ months. In TR+ group, 2 patients (8.7\%) died because of heart failure and 1 patient died in a traffic accident. In TR- group 1 patient (8.33\%) died because of heart failure and 1 patient had heart transplantation (results were statistically insignificant).

Conclusions. We couldn't prove that the worsening of TR was associated with worsening of clinical outcome. Further studies are needed to assess an influence of LITR on prognosis in patients with ARVC and ICD implanted.

Key words: arrhythmogenic right ventricular cardiomyopathy, tricuspid regurgitation, implantable cardioverter-defibrillator, sudden cardiac death
\end{abstract}

Folia Cardiologica 2016; 11, 5: 365-371

\section{Introduction}

Arrhythmogenic right ventricular cardiomyopathy (ARVC) is an inheritable disease characterized by progressive fibrofatty replacement of the cardiac muscle. Its estimated prevalence is 1:2,500-1:5,000 [1]. Molecular studies prove that ARVC is mainly a disease of intercellular junctions [2]. Heterogenic mutations have been found in different

Address of correspondence: lek. Krzysztof Bernard Poślednik, Instytut Kardiologii, ul. Alpejska 42, 04-628 Warszawa-Anin, Poland,

e-mail: krzysztof.poslednik@gmail.com 
proteins responsible for cell-to-cell adhesion, resulting in detachment of the cardiomyocytes and their susceptibility to mechanical stress.

Clinical manifestations in ARVC are typically associated with the right ventricle (RV), although involvement of the left ventricle (LV) is not rare. Classical features of the disease are RV dilatation and RV regional or global systolic dysfunction [3]. Progressive RV dilatation may lead to secondary worsening of tricuspid regurgitation (TR), which contributes to further decrease in RV stroke volume [4].

Clinical presentation of ARVC consists of palpitations (66.9\% pts), syncope (32.3\% pts), atypical chest pain (26.9\% pts), dyspnea (10.8\% pts) and clinical signs of right ventricular failure (6.2\% pts) [5]. In some cases the first symptom of the disease is sudden cardiac death (SCD) [6].

Patients with high risk of adverse outcome usually receive implantable cardioverter-defibrillator (ICD) as a prevention of SCD. Unfortunately, the insertion of ICD into the right ventricle is supposed to exacerbate tricuspid regurgitation. Significant tricuspid regurgitation, according to the recent research, may negatively affect prognosis in patients with ARVC [4]. However, up to the present moment the risk of TR progression after ICD implantation and its possible consequences in patients with ARVC have not been fully established.

The aim of our study was to assess the progression of TR and its clinical outcome in a group of high-risk patients with ARVC who underwent ICD implantation.

\section{Material and methods}

Study population consisted of 35 patients (pts) out of 55 pts with ARVC and ICD implanted in primary as well as in secondary prevention. Twenty pts were excluded because of incomplete data. Secondary prevention was provided to patients with a history of cardiac arrest, hemodynamically unstable ventricular tachycardia and syncope. The enrollment criteria were: a confirmed diagnosis of ARVC (according to the Revised Task Force Criteria published in 2010), implanted ICD and complete echocardiographic data. All data collected between 1995 and 2014 came from medical registry of the Institute of Cardiology. These included: clinical presentation before implantation of the ICD, family history, ECG and 24-hour Holter recordings, antiarrhythmic agents used, echocardiography data, information about ICD interventions.

The group consisted of 29 males (83\%) and 6 females, mean age $48.78 \pm 13.56$ years (ranging from 26 to 71 ). Seventeen (48.57\%) patients had signs and symptoms of heart failure before ICD implantation, twelve (34.29\%) patients had a history of regular sport activity before that procedure. Family history of ARVC was reported in 9 pts (25.71\%). Mean time of observation was $91.06 \pm$ \pm 55.32 months.
All patients were given appropriate treatment for arrhythmias, heart failure and concomitant afflictions such as major depressive disorder or generalized anxiety disorder.

The ICD was implanted in primary - $24(68.57 \%)$ and secondary -11 (31.43\%) prevention of SCD. The mean age at ICD implantation was $39.89 \pm 13.90$ years.

Eight pts (22.86\%) had implanted cardiac pacemaker before implantation of ICD. Moreover, in case of 4 patients cardiac resynchronization therapy (CRT-D) was used according to clinical indications.

Sixteen $(48.48 \%)$ pts underwent radiofrequency ablation of arrhythmia substrate.

Data of general population are collected in Table 1.

\section{Echocardiography}

Transthoracic echocardiography (TTE) was performed using ultrasound transducers Vivid 6, Vivid 7 and Sonos 5500 to estimate TR and other parameters such as ejection fraction of the left ventricle, PLAX RVOT (parasternal long axis right ventricular outflow tract) and TAPSE (tricuspid annular plane systolic excursion).

Echocardiographic examinations were performed before and after ICD implantation. The mean time from ICD implantation to second echocardiographic examination was $32.71 \pm 27.14$ months. Subjective visual assessment of TR in four-grade scale was made by assessment of retrograde systolic flow from the right ventricle to the right atrium in transthoracic apical view. Worsening of TR was defined as its deterioration to higher grade (e.g. from grade II to grade III or IV). On this basis patients were divided into two groups. Patients with worsening of TR constituted $\mathrm{TR}+$ group, patients without worsening of TR constituted TR- group.

\section{Implantable cardioverter-defibrillator}

The ICD interventions were classified as appropriate or inappropriate by experienced electrophysiologist on the basis of stored intracardiac electrograms.

\section{Follow-up}

Patients were seen in outpatient clinic every 6-12 months, according to clinical needs. When appropriate, information about outcome was obtained from patient's physician or from members of his or her family.

\section{Primary and secondary end-points}

Primary end-points were cardiovascular death or orthotopic heart transplantation (OHT). Secondary end-points were adequate as well as inadequate interventions of ICD.

\section{Statistical analysis}

Mean \pm standard deviation, total number and percentage were used to demonstrate the data. The $t$-Student test 
Table 1. Clinical, electrocardiographic (ECG) and echocardiographic $(\mathrm{ECHO})$ characteristics of general study population

$\begin{array}{ccc}\text { Parameter } & \begin{array}{c}\text { General } \\ \text { study po- } \\ \text { pulation }\end{array} & \begin{array}{c}\text { Number of } \\ \text { pts with lac- } \\ \text { king data }\end{array}\end{array}$

\section{General characteristics}

Males [\%]

Mean age (years)

$\begin{array}{cc}83 & 0 \\ 47 \pm 13 & 0 \\ 40 \pm 14 & 0 \\ 23 & 0\end{array}$

Anamnesis before ICD implantation

Cardiac arrest [\%]

$31 \quad 0$

Syncope [\%]

Palpitations [\%]

Family history of ARVC [\%]

Signs and symptoms

of heart failure [\%]

RF ablation [\%]

ECG parameters before ICD implantation

Epsilon waves [\%]

56

Echocardiogram findings

LV dysfunction [\%]:

$\begin{array}{lll}\text { ECHO } 1 & 43 & 0 \\ \text { ECHO } 2 & 32 & 0\end{array}$

Mean LVEF [\%]:

$\begin{array}{lll}\text { ECHO } 1 & 59 \pm 14 & 1 \\ \text { ECHO } 2 & 57 \pm 15 & 2\end{array}$

RV systolic dysfunction [\%]:

$\begin{array}{ccc}\text { ECHO } 1 & 29 & 0 \\ \text { ECHO } 2 & 43 & 0 \\ \text { RV enlargement** [\%]: } & & \\ \text { ECHO } 1 & 79 & 2 \\ \text { ECHO } 2 & 86 & 0\end{array}$

RV borderline

enlargement $* * *[\%]$ :

ECHO 1

12

2

ECHO 2

11

0

ICD interventions

$\begin{array}{lll}\text { Adequate [\%] } & 60 & 0 \\ \text { Inadequate [\%] } & 29 & 0\end{array}$

*ECG parameters before ICD implantation in these pts were unavailable, **PLAX RVOT $\geq 32 \mathrm{~mm}$; major diagnostic criterion (Revised [2010] task force criteria for diagnosis of ARVC); ***PLAX RVOT $\geq 29-31 \mathrm{~mm}$; minor diagnostic criterion (Revised [2010] task force criteria for diagnosis of ARVC); pts - patients; ICD - implantable cardioverter-defibrillator; RF - radiofrequency; ARVC arrhythmogenic right ventricular cardiomyopathy; LV - left ventricle; ECHO 1- echocardiographic examination prior to ICD implantation; ECHO 2 - echocardiographic examination after ICD implantation; LVEF - left ventricular ejection fraction; RV - right ventricle

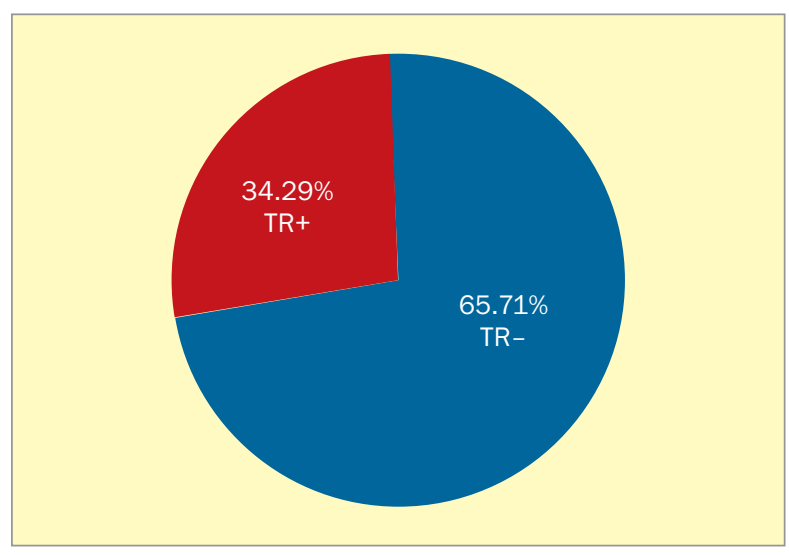

Figure 1. Occurrence of tricuspid regurgitation in general study population; TR+ group with deterioration of tricuspid insufficiency after ICD implantation, TR- group with no worsening of tricuspid regurgitation

and Wilcoxon test were used for continuous variables and the Fisher exact test for categorical variables. Statistical analysis was performed with SAS 9.2 software.

\section{Results}

\section{Tricuspid regurgitation (Figure 1)}

$\mathrm{TR}+$ group was composed of 23 (65.71\%) pts in whom the worsening of tricuspid regurgitation was found: $18 \mathrm{ma}-$ les (78.26\%) and 5 females. Mean age in this group was $46.13 \pm 14.13$ years. ICD was implanted in secondary prevention in 6 pts (26.09\%).

TR-group included 12 pts without worsening of tricuspid regurgitation: 11 males (91.67\%) and 1 female, mean age: $48.67 \pm 12.47$ years. ICD was implanted in secondary prevention in 5 pts (41.67\%).

\section{Signs and symptoms of heart failure}

In TR+ group signs and symptoms of heart failure (HF) were present in $43.48 \%$ of patients before ICD implantation (17.39\% in class III of New York Heart Association [NYHA] Functional Classification, 0 in class IV), and in $100 \%$ of pts in the follow-up (class III $21.74 \%$, class IV $4.35 \%$ ).

In TR-group signs and symptoms of HF were present in 58.33\% of patients before ICD implantation (class III of NYHA 33.33\%, class IV 8.33\%) and in $91.67 \%$ of pts after ICD implantation (0 in class III, $16.67 \%$ in class IV).

\section{Echocardiogram findings}

In TR+ group, the mean PLAX RVOT was $37.43 \pm 8.48 \mathrm{~mm}$ before ICD implantation and $42.52 \pm 10.79 \mathrm{~mm}$ after the implantation. 


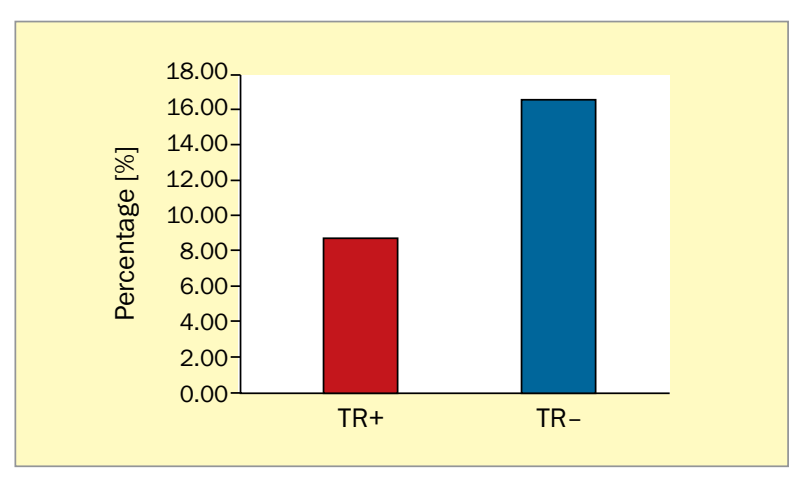

Figure 2. Primary end-points (cardiac death or heart transplantation necessity) in TR+ and TR-group; results non-significant; TR+ group with deterioration of tricuspid insufficiency after ICD implantation, TR- group with no worsening of tricuspid regurgitation

In TR-group, the mean RVOT was $40.5 \pm 8.22 \mathrm{~mm}$ before ICD implantation, and $41.33 \pm 6.02 \mathrm{~mm}$ after the procedure.

These results were statistically insignificant $(p=0.34$ and $p=0.68$ for mean RVOT before and after ICD implantation, respectively).

Worsening of TR was associated with dysfunction of the left ventricle (defined as ejection fraction $<55 \%$ or impaired contractility) in the follow-up echocardiogram; it was found in 9 patients (39.13\%) in TR+ group and only in $2(18.18 \%)$ patients in TR- group. However, these results were not statistically significant $(p=0.16)$.

\section{Primary end-points (Figure 2)}

During a follow-up of $91.06 \pm 55.32$ months there were 4 deaths (11.43\%), 3 due to heart failure and 1 non-cardiac (traffic accident). One (2.86\%) patient underwent orthotopic heart transplantation.

In TR+ group 3 patients (13.04\%) died - 2 (8.7\%) pts due to HF.

In TR- group there was 1 (8.33\%) cardiac death (because of $\mathrm{HF}$ ) and $1 \mathrm{OHT}(8.33 \%)$.

No SCD occurred during follow-up. Primary end-points data were not statistically significant.

\section{Secondary end-points (Figure 3 )}

In TR+ group adequate interventions of ICD were found in $15(65.22 \%)$ individuals, inadequate - in 9 (39.13\%) patients.

In TR- group adequate interventions of ICD occurred in 6 pts (50\%) and inadequate in 1 (8.33\%).

$P$ value for adequate interventions was 0.48 , and for inadequate 0.11 .

No ICD interventions occurred in 5 pts (21.74\%) in TR+ group versus $6(50 \%)$ in TR- group $(p=0.13)$.

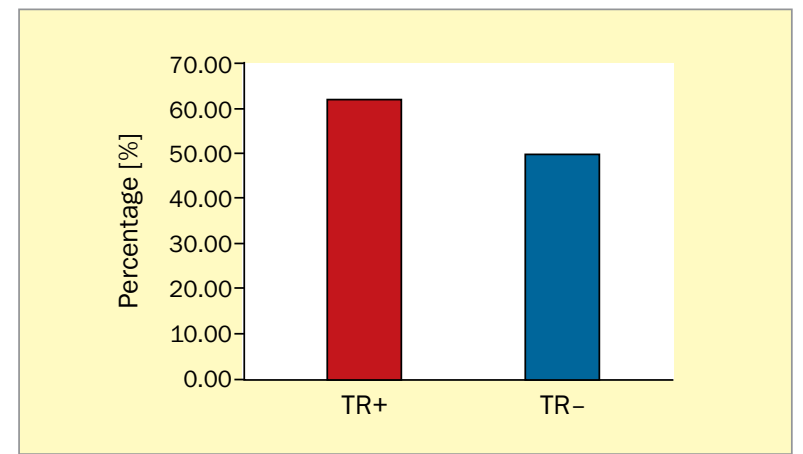

Figure 3. Secondary end-points - adequate ICD interventions in both study groups (TR+ and TR-); $p=0.48$; TR+ group with deterioration of tricuspid insufficiency after ICD implantation, TR- group with no worsening of tricuspid regurgitation

Clinical characteristics in both study groups are presented in Table 2.

\section{Discussion}

The importance of tricuspid regurgitation in patients with ARVC after ICD implantation seems to be still under-recognized. In Pinamonti et al. study [4] prevalence of significant tricuspid regurgitation was $15 \%$ in ARVC patients (with and without ICD or pacemaker). In medical literature available data are scarce.

Our study demonstrated that implantation of ICD can possibly worsen the tricuspid regurgitation. We didn't prove that lead-induced TR in ARVC patients had negative impact on their prognosis, but we feel that a study with increased number of patients would have statistical power to prove otherwise.

The risk of lead-induced tricuspid regurgitation (LITR) should be taken into account in ARVC patients with ICD. Severe TR is supposed to cause higher risk of cardiovascular death/OHT in patients with ARVC [4]. Potentially, it can cause a necessity of valve repair or replacement - as described in a report of 41 such patients (six with an ICD); the mean time from device placement to surgery was 72 months (range 2 to 228 months) [7]. Several mechanisms may be involved in this entity. Perforation of the tricuspid valve (TV) leaflet by the intracardiac lead, entanglement of the lead with the TV, impingement of the TV leaflets, lead adherence to the TV and chordal entanglement are reported among others [7-9]. Various studies show prevalence of LITR ranging from $7.2 \%$ to $39 \%$ [8]. This data scatter comes partially from different ways of TR assessment. In our study retrograde systolic flow from the right ventricle to the right atrium was assessed visually in transthoracic echocardiography and expressed in grades 1-4. 
Table 2. Data of patients in both study groups (TR+ group with deterioration of tricuspid insufficiency after implantable cardioverter-defibrillator [ICD] implantation, TR- group with no worsening of tricuspid regurgitation)

\begin{tabular}{|c|c|c|c|}
\hline Parameter & $\begin{array}{l}\text { TR+ group } \\
(\mathrm{n}=23)\end{array}$ & $\begin{array}{l}\text { TR- group } \\
(\mathrm{n}=12)\end{array}$ & $P$ value \\
\hline \multicolumn{4}{|l|}{ General characteristics } \\
\hline Males [\%] & 78 & 92 & NS \\
\hline Mean age (years) & $46.13 \pm 14.13$ & $48.67 \pm 12.47$ & NS \\
\hline Age at implantation (years) & $39 \pm 15$ & $42 \pm 13$ & NS \\
\hline Pacemaker implanted (\%) & 26 & 17 & NS \\
\hline \multicolumn{4}{|l|}{ Anamnesis before ICD implantation } \\
\hline Cardiac arrest [\%] & 26 & 42 & NS \\
\hline Syncope [\%] & 61 & 83 & NS \\
\hline Palpitations [\%] & 74 & 75 & NS \\
\hline Family history of ARVC [\%] & 35 & 9 & NS \\
\hline Signs and symptoms of heart failure [\%] & 43 & 58 & NS \\
\hline RF ablation [\%] & 50 & 45 & NS \\
\hline \multicolumn{4}{|l|}{ ECG parameters } \\
\hline Epsilon waves [\%] & 53 & 63 & NS \\
\hline \multicolumn{4}{|l|}{ Echocardiogram findings } \\
\hline \multicolumn{4}{|l|}{ LV dysfunction [\%]: } \\
\hline ECHO 1 & 39 & 50 & NS \\
\hline ECHO 2 & 39 & 18 & NS \\
\hline \multicolumn{4}{|l|}{ Mean LVEF [\%]: } \\
\hline ECHO 1 & $58 \pm 15$ & $62 \pm 10$ & NS \\
\hline ECHO 2 & $55 \pm 17$ & $61 \pm 11$ & NS \\
\hline \multicolumn{4}{|l|}{ RV systolic dysfunction [\%]: } \\
\hline ECHO 1 & 30 & 25 & NS \\
\hline ECHO 2 & 39 & 50 & NS \\
\hline \multicolumn{4}{|l|}{ RV enlargement* [\%]: } \\
\hline ECHO 1 & 78 & 80 & NS \\
\hline ECHO 2 & 83 & 92 & NS \\
\hline \multicolumn{4}{|l|}{ RV borderline enlargement** [\%]: } \\
\hline ECHO 1 & 9 & 20 & NS \\
\hline ECHO 2 & 13 & 8 & NS \\
\hline \multicolumn{4}{|l|}{ ICD interventions } \\
\hline Adequate [\%] & 65 & 50 & NS \\
\hline Inadequate [\%] & 39 & 8 & NS \\
\hline
\end{tabular}

*PLAX RVOT $\geq 32 \mathrm{~mm}$; major diagnostic criterion (Revised [2010] task force criteria for diagnosis of ARVC); **PLAX RVOT $\geq 29-31 \mathrm{~mm}$; minor diagnostic criterion (Revised [2010] task force criteria for diagnosis of ARVC); NS - non-significant; ARVC - arrhythmogenic right ventricular cardiomyopathy; RF - radiofrequency; ECG - electrocardiography; LV - left ventricle; ECHO 1 - echocardiographic examination prior to ICD implantation; ECHO 2 - echocardiographic examination after ICD implantation; LVEF - left ventricular ejection fraction; RV - right ventricle

In our study, worsening of tricuspid regurgitation occurred in $65.71 \%$ of study population (males $78.26 \%$ ), probably due to ICD. This observation is crucial, because lead-induced TR is supposed to worsen the clinical outco- me. Perhaps in the case of ARVC patients with indications for ICD implantation some alternative approaches should be considered, like placement of an epicardial ventricular lead or transvenous LV lead via the coronary sinus. 
Establishing our study we hypothesized that ICD (or CRT-D) implantation could have negative prognostic value for patients suffering from ARVC. According to this hypothesis, when the right ventricle is affected by the disease, LITR may cause its additional enlargement and remodeling translating into negative outcomes, such as heart failure, death or necessity of heart transplantation. However, the study didn't show statistical difference between groups TR+ and TR-regarding primary end-points.

\section{ICD interventions}

Appropriate ICD interventions are believed to terminate arrhythmias, which otherwise might cause sudden cardiac death [10]. We noticed discrepancy in the number of adequate ICD interventions between two groups. Namely, adequate ICD interventions happened more often in the group with TR deterioration in contrast to the second group (65.22\% vs $50 \%)$.

On the other hand progressive tricuspid valve regurgitation could reflect the degree of overt cardiac muscle damage. That, in fact, could be responsible for increased number of ventricular arrhythmias due to macro-re-entry mechanism, marking a progression into 'electrical' phase of ARVC [1].

\section{Left ventricle involvement}

Left ventricle involvement is supposed to increase the risk of SCD [11].

In our study, $42.86 \%$ of patients presented with the involvement of the left ventricle by disease process in echocardiography examination before ICD implantation (defined as left ventricle ejection fraction below 55\% or systolic impairment in echocardiographic examination). One study suggested that percentage of patients with CMR evidence of LV involvement may be as high as 84\% [12]. This shows the necessity of broader consideration of ARVC as a disease of both ventricles.

\section{Study limitations}

First of all, it is difficult to establish whether TR worsening in ARVC is the result of LITR or just a natural course of the disease. However, we assume that LITR was a leading reason of TR worsening because mean time from ICD implantation to control echocardiogram was relatively short (32.71 \pm 27.14 months), probably inadequate for a considerable progress of the disease.

The most important limitation of our study was small number of patients included into the study. We feel that because of this some of the data were statistically insignificant.

$A R V C$ is relatively rare disease and its first manifestation can be SCD or recurrent ventricular arrhythmia threatening one's life. In some survivors of cardiac arrest ICD was implanted prior to detailed echocardiographic assessment and we had to exclude these patients from our study.

\section{Conclusions}

The study had no statistical power to prove that LITR is associated with worsening of the prognosis in patients with ARVC and high risk of sudden cardiac death. We assume that increased number of patients involved into the study would prove otherwise. Differences in outcome between both groups (with and without worsening of tricuspid regurgitation) were statistically insignificant.

\section{Contribution statement}

All authors listed have contributed sufficiently to the project to be included as authors, and all those who are qualified to be authors are listed in the author byline.

\section{Acknowledgments}

None.

\section{Funding}

This research received no grant from any funding agency in the public, commercial or not-for-profit sectors.

\section{Conflict of interest(s)}

The Authors declare that there is no conflict of interest. 


\section{Streszczenie}

Wstęp. Problem niedomykalności zastawki trójdzielnej po implantacji elektrody prawokomorowej (LITR) u chorych z arytmogenną kardiomiopatią prawej komory (ARVC) nie został dostatecznie zbadany. U chorych obciążonych wysokim ryzykiem zdarzeń sercowych zwykle stosuje się wszczepialny kardiowerter-defibrylator (ICD) w ramach prewencji nagłego zgonu sercowego (SCD). Jednak uważa się, że wprowadzenie elektrody ICD do prawej komory może powodować pogorszenie niedomykalności zastawki trójdzielnej.

W związku z tym, że u wielu chorych konieczne jest wszczepienie ICD (lub urządzenia do terapii resynchronizującej serca) w ramach prewencji SCD autorzy postanowili ocenić częstość występowania LITR oraz rokowanie w tej grupie chorych.

Materiał i metody. Spośród 55 chorych z ARVC i ICD wszczepionym w ramach prewencji SCD autorzy wybrali 35 osób (średni wiek 48,78 \pm 13,56 roku), w przypadku których dostępne były dane potrzebne do analizy. Na podstawie wyników echokardiografii badaną populację podzielono na dwie grupy: grupę TR+ obejmującą osoby, u których nastąpiło pogorszenie niewydolności zastawki trójdzielnej (TR) definiowane jako pogorszenie do wyższego stopnia, oraz grupe TR- (bez pogorszenia TR).

Wyniki. U 65,71\% chorych nastąpiło pogorszenie TR po implantacji ICD. Średni czas obserwacji wynosił 91,06 \pm 55,32 miesiąca. W grupie TR+ 2 chorych (8,7\%) zmarło z powodu niewydolności serca, a 1 chory zginął w wypadku komunikacyjnym. W grupie TR- odnotowano zgon 1 chorego (8,33\%) z powodu niewydolności serca, a 1 chorego poddano transplantacji serca (dane nieistotne statystycznie).

Wnioski. Autorzy nie wykazali, by pogorszenie TR wiązało się z gorszym efektem klinicznym. Potrzebne są dalsze badania w celu oceny wpływu LITR na rokowanie u chorych z ARVC, którym wszczepiono ICD.

Słowa kluczowe: arytmogenna kardiomiopatia prawej komory, niedomykalność zastawki trójdzielnej, wszczepialny kardiowerter-defibrylator, nagły zgon sercowy

Folia Cardiologica 2016; 11, 5: 365-371

\section{References}

1. Thiene G., Corrado D., Basso C. Arrhythmogenic right ventricular cardiomyopathy/dysplasia. Orphanet J. Rare Dis. 2007; 2: 45.

2. Xu T., Yang Z., Vatta M. et al. Compound and digenic heterozygosity contributes to arrhythmogenic right ventricular cardiomyopathy. J. Am. Coll. Cardiol. 2010; 55: 587-597.

3. Marcus F.I., McKenna W.J., Sherrill D. et al. Diagnosis of arrhythmogenic right ventricular cardiomyopathy/dysplasia: proposed modification of the Task Force Criteria. Eur. Heart J. 2010; 31: 806-814.

4. Pinamonti B., Dragos A.M., Pyxaras S.A. et al. Prognostic predictors in arrhythmogenic right ventricular cardiomyopathy: results from a 10 -year registry. Eur. Heart J. 2011; 32: 1105-1113.

5. Hulot J.S., Jouven X., Empana J.P. et al. Natural history and risk stratification of arrhythmogenic right ventricular dysplasia/cardiomyopathy. Circulation 2004; 110: 1879-1884.

6. Thiene G., Nava A., Corrado D. Right ventricular cardiomyopathy and sudden death in young people. N. Engl. J. Med. 1988; 318: 129-133.

7. Lin G., Nishimura R.A., Connolly H.M. et al. Severe symptomatic tricuspid valve regurgitation due to permanent pacemaker or implantable cardioverter-defibrillator leads. J. Am. Coll. Cardiol. 2005; 45: 1672-1675.
8. Al-Mohaissen M.A., Chan K.L. Prevalence and mechanism of tricuspid regurgitation following implantation of endocardial leads for pacemaker or cardioverter-defibrillator. J. Am. Soc. Echocardiogr. 2012; 25: 245-252.

9. Pfannmueller B., Hirnle G., Seeburger J. et al. Tricuspid valve repair in the presence of a permanent ventricular pacemaker lead. Eur. J. Cardiothorac. Surg. 2011; 39: 657-661.

10. Schinkel A.F., Vriesendorp P.A., Sijbrands E.J. et al. Outcome and complications after implantable cardioverter defibrillator therapy in hypertrophic cardiomyopathy systematic review and meta-analysis. Circ. Heart Fail. 2012; 5: 552-559.

11. Saguner A.M., Brunckhorst C., Duru F. Arrhythmogenic ventricular cardiomyopathy: A paradigm shift from right to biventricular disease. World J. Cardiol. 2014; 6: 154-174.

12. Sen-Chowdhry S., Syrris P., Ward D. et al. Clinical and genetic characterization of families with arrhythmogenic right ventricular dysplasia/ /cardiomyopathy provides novel insights into patterns of disease expression. Circulation 2007; 115: 1710-1720. 